Шовкова О. В., аспірант

(науковий керівник - доктор сільськогосподарських наук, професор М. Я. Шевніков)

Полтавська державна аграрна академія

\title{
ФОТОСИНТЕТИЧНА ПРОДУКТИВНІСТЬ ПОСІВІВ СОЇ ЗАЛЕЖНО ВІД СТРОКІВ СІВБИ ТА СПОСОБІВ ЗАСТОСУВАННЯ МІКРОДОБРИВ
}

\section{Рецензент - доктор сільськогосподарських наук, професор П. В. Писаренко}

Фотосинтезуюча діяльність посівів сільськогосподарських культур, у тому числі й сої, $є$ головною складовою формування їх продуктивності. Оптимальний ріст листкової поверхні та накопичення сухої речовини рослинами сої значною мірою залежить від обтрунтованості технологій вирощування, щзо забезпечать більи тривалу роботу листкового апарату.

Обробка насіння мікродобривом на хелатній основі «Рексолін» та позакореневе підживлення «Рексоліном» $i$ «Брасітрелом» за різних строків сівби сої активізувало фотосинтетичну діяльність посівів даної культури.

Комплексне застосування мікродобрив на насінні та по вегетуючих рослинах сприяло формуванню максимальних показників площуі листя й чистої продуктивності фотосинтезу.

Ключові слова: строки сівби, позакореневе підживлення, мікродобрива, «Рексолін», «Брасітрел», площа листкової поверхні, чиста продуктивність фотосинтезу.

Постановка проблеми. Соя вже багато років належить до найважливіших культур світового землеробства й $\epsilon$ найпоширенішою серед зернобобових і олійних культур.

Ïї вирощують на всіх континентах, оскільки вона відіграє вирішальну роль у зерновому, харчовому та кормовому балансах.

Соя дає змогу швидко підвищувати культуру землеробства, поліпшувати родючість грунту, збільшувати обсяги доступних харчових продуктів і кормів за помірнішою ціною [1].

Вона має центральне місце у вирішенні проблеми білка, так як його вміст у насінні цієї культури становить 38-40 \% і включає необхідний набір найцінніших амінокислот.

На сьогодні площі вирощування сої в Україні зростають, але урожайність залишається ще на невисокому рівні.

Це $\epsilon$ результатом недостатнього вивчення процесів росту й розвитку посівів даної культури.

Тому дослідження впливу основних фізіологічних процесів на продуктивність сої є актуальним, оскільки пов'язане 3 удосконаленням технології вирощування.
Аналіз основних досліджень і публікацій, у яких започатковано розв'язання проблеми. Фотосинтез $є$ найбільш характерною і важливою особливістю зелених рослин. Це основне джерело формування їх біомаси. У процесі фотосинтезу рослини за рік утворюють близько 400 млрд тонн органічної речовини, виділяючи близько 460 млрд тонн кисню [7].

Найбільше накопичення (90-95\%) сухої маси урожаю відбувається шляхом фотосинтезу в листках [5]. Головними факторами, що впливають на величину врожаю рослин сої, $є$ розмір листкової поверхні та іiї продуктивний період, тобто тривале перебування в активному стані. За твердженням А. О. Ничипоровича [4], оптимальна площа листків має коливатися в межах 40-50 тис. м² на 1 гектар. У процесі формування листкової площі понад 60 тис. м² на 1 га - явище негативне, поскільки порушується нормальний газообмін та освітленість у посівах, внаслідок чого знижується продуктивність фотосинтезу.

Біологічне значення розмірів листкової поверхні, передусім, полягає в тому, що від них залежить ступінь поглинання посівами фотосинтетично активної радіації (ФАР). Однією 3 основних умов для максимально ефективного використання енергіï сонця $є$ формування рослинами оптимальної листкової поверхні й тривале їх перебування в активному стані. Як відзначав А. О. Ничипорович, для одержання високого врожаю недостатньо сформувати велику площу асиміляційної поверхні, а отримавши іiі, неможливо гарантувати високу врожайність культури [8].

Досить важливим показником фотосинтетичної діяльності в посівах є чиста продуктивність фотосинтезу (ЧПФ), що характеризує інтенсивність нагромадження сухої біомаси врожаю протягом доби в розрахунку на $1 \mathrm{~m}^{2}$ листкової поверхні рослин. Задовільними є показники чистої продуктивності фотосинтезу, що мають значення в межах 3-4 г/м² за добу, хороші - 4-6, дуже хороші - понад 6 г сухої речовини на $1 \mathrm{~m}^{2}$ площі листків за добу $[2,6]$.

Все рослинництво - це система найкращого 


\section{СТОРІНКА МОЛОДОГО ВЧЕНОГО}

використання фотосинтетичної функції рослин. Із цієї точки зору кожний агротехнічний прийом, що має за мету збільшення врожайності, виявляється ефективним у тих випадках, якщо він дає можливість одержувати в посівах таку площу листя, що швидко розвивається й досягає великих розмірів; якщо він підвищує інтенсивність і продуктивність роботи кожного квадратного метра площі листків і зберігає їх в активному стані можливо більш тривалий час; якщо він сприяє найкращому використанню продуктів фотосинтезу [3, 4].

Мета і завдання дослідження. Метою дослідження було встановити вплив передпосівної обробки насіння та позакореневого підживлення рослин сої мікродобривами за різних строків сівби на формування фотосинтетичної продуктивності посівів.

Завдання досліджень - вивчити потенціал формування площі листкової поверхні рослинами сої за умови проведення різних способів застосування мікродобрив за раннього, оптимального та пізнього строків сівби й розрахувати основні показники фотосинтетичної діяльності посівів сої.

Матеріали і методи досліджень. Польові дослідження проводились у 2013 році на дослідному полі Полтавської державної сільськогосподарської дослідної станції ім. М. І. Вавилова Інституту свинарства і АПВ НААН України.

Грунт дослідної ділянки - чорнозем типовий середньогумусний важкосуглинковий. Його орний шар характеризується такими основними агрохімічними показниками: вміст гумусу 4,9 \%; азоту, що легко гідролізується (за Корнфільдом), - 12,7 мг; фосфору (за Чириковим) 10,3 мг, обмінного калію (за Масловою) 17,1 мг/100 г грунту, $\mathrm{pH}$ (сольове) - 6,5.

Технологія вирощування сої - загальноприйнята для зони лісостепу, крім елементів технології, що досліджувалися. Сорт сої - Алмаз. Площа дослідної ділянки - $25 \mathrm{~m}^{2}$, облікової - 17,25 м² у трьохразовому повторенні. Сіяли сою в три строки, керуючись температурними показниками грунту: ранній - за температури грунту $10{ }^{\circ} \mathrm{C}$ на глибині 0-10 см; оптимальний - за температури $12{ }^{\circ} \mathrm{C}$ на глибині 0-10 cм; пізній - за температури грунту $14{ }^{\circ} \mathrm{C}$ на глибині 0-10 сантиметpiв.

Вивчали такі мікродобрива: «Рексолін» і «Брасітрел». Насіння перед сівбою обробляли розчином «Рексоліну» 3 розрахунку 150 г сухої речовини на тонну насіння, після чого підсушували до сипучого стану.

У період вегетації проводили позакореневі підживлення водорозчинними мікродобривами «Рексолін» у нормі 500 г/га та «Брасітрел» із витратою робочої рідини 3 літри на гектар.

Результати досліджень. Вивчення динаміки формування площі листкової поверхні сої показало, що найбільшого значення вона досягла у фазі наливання насіння, коли рослини в більшій мірі потребують продуктів фотосинтезу для їх накопичення у насінні.

Застосування мікродобрива «Рексолін» для обробки насіння у поєднанні 3 позакореневими підживленнями «Рексоліном» та «Брасітрелом» сприяло активному наростанню листкової поверхні, й у фазі наливання насіння площа листя на цих варіантах за раннього строку сівби (за температури грунту $10{ }^{\circ} \mathrm{C}$ на глибині 0-10 см) була

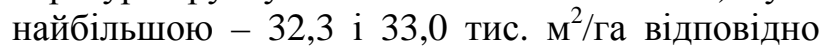
(табл. 1).

Використання хелатного мікродобрива «Рексолін» для обробки насіння активізувало наростання листкової поверхні сої в період цвітінняутворення бобів. Площа листя перевищувала цей показник для контрольного варіанта від 4,2 тис. $\mathrm{m}^{2} /$ га в фазу цвітіння до 7,1 тис. $\mathrm{m}^{2} /$ га - у фазу утворення бобів на ділянках раннього строку сівби, від 6,2 тис. м $^{2} /$ га до 6,8 тис. $\mathrm{m}^{2} /$ га - за оптимального строку сівби, від 4,5 тис. $\mathrm{m}^{2} /$ га у фазу цвітіння до 3,6 тис. м $^{2} /$ га - у фазу утворення бобів на ділянках пізнього строку сівби.

Позитивно на наростання площі листя впливали й позакореневі підживлення «Рексоліном» та «Брасітрелом». Мікроелементи, що входять до складу цих мікродобрив, сприяють збільшенню хлорофілу в листках, посиленню асиміляційної діяльності рослин, подовженню роботи листкового апарату. Так, зокрема, обробка вегетуючих рослин сої мікродобривом на хелатній основі «Рексолін» забезпечило зростання листкової поверхні у фазу цвітіння, порівняно 3 контролем, на 23,5 \% для посівів першого строку, на 32,7 \% - для другого і 40,2 \% - для третього.

Схожа закономірність спостерігалася і в разі позакореневого підживлення «Брасітрелом» - на $22,7 \%, 30,5 \%$ та 31,3\% відповідно.

Поєднання позакореневого підживлення посівів сої «Рексоліном» та «Брасітрелом» на фоні передпосівної обробки насіння «Рексоліном» забезпечило максимальне зростання площ листкової поверхні.

У порівнянні з ділянками контрольного варіанта приріст становив для трьох строків сівби, відповідно: 27,2; 41,5 і 35,1\% за поєднання «Рексолін»+ «Рексолін» і 28,8; 38,3 і 36,0 \% - за поєднання «Рексолін» + «Брасітрел». 
СТОРІНКА МОЛОДОГО ВЧЕНОГО

\section{1. Динаміка наростання площі листкової поверхні рослин сої}

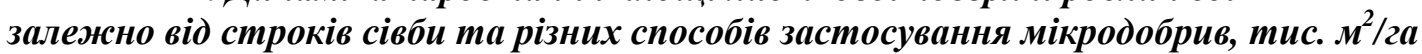

\begin{tabular}{|c|c|c|c|}
\hline \multirow{2}{*}{ Варіант } & \multicolumn{3}{|c|}{ Фази росту і розвитку рослин } \\
\hline & цвітіння & утворення бобів & наливання насіння \\
\hline \multicolumn{4}{|c|}{ Сівба за температури грунту $10{ }^{\circ} \mathrm{C}$ на глибині $0-10$ см } \\
\hline Контроль & 16,3 & 17,8 & 23,5 \\
\hline Обробка насіння водою & 18,7 & 20,3 & 25,7 \\
\hline Обробка насіння «Рексоліном» & 20,5 & 24,9 & 27,1 \\
\hline Позакореневе підживлення «Рексоліном» & 21,3 & 27,1 & 29,1 \\
\hline $\begin{array}{c}\text { Обробка насіння «Рексоліном» } \\
\text { та позакореневе підживлення «Рексоліном» }\end{array}$ & 22,2 & 28,4 & 32,3 \\
\hline Позакореневе підживлення «Брасітрелом» & 21,1 & 27,2 & 30,3 \\
\hline $\begin{array}{c}\text { Обробка насіння «Рексоліном» } \\
\text { та позакореневе підживлення «Брасітрелом» }\end{array}$ & 21,8 & 29,0 & 33,0 \\
\hline \multicolumn{4}{|c|}{ Сівба за температури грунту $12^{\circ} \mathrm{C}$ на глибині $0-10 \mathrm{~cm}$} \\
\hline Контроль & 10,5 & 13,8 & 16,1 \\
\hline Обробка насіння водою & 12,6 & 15,8 & 19,8 \\
\hline Обробка насіння «Рексоліном» & 16,7 & 20,6 & 23,6 \\
\hline Позакореневе підживлення «Рексоліном» & 15,6 & 19,8 & 23,2 \\
\hline $\begin{array}{c}\text { Обробка насіння «Рексоліном» } \\
\text { та позакореневе підживлення «Рексоліном» }\end{array}$ & 17,2 & 23,2 & 27,5 \\
\hline Позакореневе підживлення «Брасітрелом» & 15,1 & 19,3 & 21,8 \\
\hline $\begin{array}{c}\text { Обробка насіння «Рексоліном» } \\
\text { та позакореневе підживлення «Брасітрелом» }\end{array}$ & 17,9 & 22,9 & 26,1 \\
\hline \multicolumn{4}{|c|}{ Сівба за температури грунту $14{ }^{\circ} \mathrm{C}$ на глибині $0-10$ см } \\
\hline Контроль & 7,9 & 12,0 & 14,6 \\
\hline Обробка насіння водою & 9,7 & 13,6 & 16,6 \\
\hline Обробка насіння «Рексоліном» & 12,4 & 15,6 & 19,3 \\
\hline Позакореневе підживлення «Рексоліном» & 13,2 & 16,4 & 20,2 \\
\hline $\begin{array}{c}\text { Обробка насіння «Рексоліном» } \\
\text { та позакореневе підживлення «Рексоліном» }\end{array}$ & 14,1 & 18,9 & 22,5 \\
\hline Позакореневе підживлення «Брасітрелом» & 11,5 & 16,0 & 19,6 \\
\hline $\begin{array}{c}\text { Обробка насіння «Рексоліном» } \\
\text { та позакореневе підживлення «Брасітрелом» }\end{array}$ & 13,7 & 18,2 & 22,8 \\
\hline
\end{tabular}

Не менш важливе значення у формуванні урожаю насіння сої належить чистій продуктивності фотосинтезу, як показника роботи фотосинтетичного апарату не лише за біометричними показниками, а й за кількістю діб активного функціонування листкового апарату.

У разі вирощування сої за технологією, що передбачала сівбу в три строки, а також різні способи застосування мікродобрив, відмічено формування

різних показників чистої продуктивності фотосинтезу, тобто накопичення абсолютно сухої речовини на одиниці площі за добу (табл. 2).

На ділянках першого строку сівби (за температури грунту $10{ }^{\circ} \mathrm{C}$ на глибині $0-10 \mathrm{~cm}$ ) у рослин сої більш інтенсивно відбувалося накопичення як сирої, так і абсолютно сухої маси, в результаті чого показники чистої продуктивності фотосинтезу були вищими, ніж у рослин інших строків сівби. Період від утворення бобів до наливання насіння сої характеризувався найбільшим накопиченням біомаси порівняно 3 попереднім періодом.

Виходячи 3 цього, зростала й продуктивність фотосинтезу - 3,32-6,55 г/м² за добу залежно від строків сівби та різних способів застосування мікродобрив.

Застосування мікродобрив за раннього строку сівби забезпечило збільшення чистої продуктивності фотосинтезу на $2,4 \%$ у разі обробки насіння «Рексоліном» і на 2,8-3,3 \% - за позакореневого підживлення «Брасітрелом» і «Рексоліном». Найсприятливіші умови для формування максимального показника чистої продуктивності 
СТОРІНКА МОЛОДОГО ВЧЕНОГО

2. Чиста продуктивність фотосинтезу посівів сої

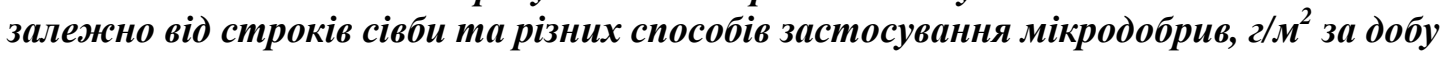

\begin{tabular}{|c|c|c|}
\hline \multirow[b]{2}{*}{ Варіант } & \multicolumn{2}{|c|}{ Фази росту і розвитку рослин } \\
\hline & $\begin{array}{c}\text { цвітіння - } \\
\text { утворення бобів }\end{array}$ & $\begin{array}{c}\text { утворення бобів - } \\
\text { наливання насіння }\end{array}$ \\
\hline \multicolumn{3}{|c|}{ Сівба за температури грунту $10^{\circ} \mathrm{C}$ на глибині $0-10 \mathrm{~cm}$} \\
\hline Контроль & 4,92 & 6,17 \\
\hline Обробка насіння водою & 4,96 & 6,28 \\
\hline Обробка насіння «Рексоліном» & 4,99 & 6,32 \\
\hline Позакореневе підживлення «Рексоліном» & 5,03 & 6,38 \\
\hline $\begin{array}{c}\text { Обробка насіння «Рексоліном» } \\
\text { та позакореневе підживлення «Рексоліном» }\end{array}$ & 5,07 & 6,45 \\
\hline Позакореневе підживлення «Брасітрелом» & 5,08 & 6,35 \\
\hline $\begin{array}{c}\text { Обробка насіння «Рексоліном» } \\
\text { та позакореневе підживлення «Брасітрелом» }\end{array}$ & 5,18 & 6,55 \\
\hline \multicolumn{3}{|c|}{ Сівба за температури грунту $12{ }^{\circ} \mathrm{C}$ на глибині $0-10$ см } \\
\hline Контроль & 4,45 & 5,71 \\
\hline Обробка насіння водою & 4,56 & 5,77 \\
\hline Обробка насіння «Рексоліном» & 4,73 & 5,94 \\
\hline Позакореневе підживлення «Рексоліном» & 4,85 & 6,05 \\
\hline $\begin{array}{c}\text { Обробка насіння «Рексоліном» } \\
\text { та позакореневе підживлення «Рексоліном» }\end{array}$ & 4,89 & 6,13 \\
\hline Позакореневе підживлення «Брасітрелом» & 4,75 & 6,03 \\
\hline $\begin{array}{c}\text { Обробка насіння «Рексоліном» } \\
\text { та позакореневе підживлення «Брасітрелом» }\end{array}$ & 4,84 & 6,07 \\
\hline \multicolumn{3}{|c|}{ Сівба за температури грунту $14{ }^{\circ} \mathrm{C}$ на глибині $0-10$ см } \\
\hline Контроль & 1,94 & 3,32 \\
\hline Обробка насіння водою & 2,08 & 3,37 \\
\hline Обробка насіння «Рексоліном» & 2,19 & 3,58 \\
\hline Позакореневе підживлення «Рексоліном» & 2,22 & 3,60 \\
\hline $\begin{array}{c}\text { Обробка насіння «Рексоліном» } \\
\text { та позакореневе підживлення «Рексоліном» }\end{array}$ & 2,25 & 3,70 \\
\hline Позакореневе підживлення «Брасітрелом» & 2,18 & 3,65 \\
\hline $\begin{array}{c}\text { Обробка насіння «Рексоліном» } \\
\text { та позакореневе підживлення «Брасітрелом» }\end{array}$ & 2,33 & 3,78 \\
\hline
\end{tabular}

фотосинтезу склалися в разі поєднання обробки насіння «Рексоліном» і позакореневих підживлень «Рексоліном» і «Брасітрелом». У період «утворення бобів - наливання насіння» продуктивність фотосинтезу в цьому випадку перевищувала даний показник для варіанта обробки насіння «Рексоліном» на $2,0 \%$ за поєднання «Рексолін» + «Рексолін» і на 3,5 \% - за поєднання «Рексолін»+ «Брасітрел».

На ділянках другого строку сівби накопичення сухої речовини за різних способів застосування мікродобрив сягало 3,9-6,9\% у період від утворення бобів до наливання насіння. Протягом попереднього періоду розвитку рослин сої показники чистої продуктивності фотосинтезу були меншими, але зростав позитивний вплив вико- ристання «Рексоліну» й «Брасітрелу» (на 0,28 0,44 г/добу).

Аналогічна тенденція спостерігалася й за третього строку сівби (температура грунту $14{ }^{\circ} \mathrm{C}$ на глибині 0-10 см), хоча за дещо нижчих абсолютних показників.

Висновки:

1. Теоретичним обгрунтуванням кожного агрозаходу вирощування сої, який певним чином позначається на іiї урожайності, є такі показники фотосинтетичної діяльності посівів як площа листкової поверхні та чиста продуктивність фотосинтезу.

2. До факторів, що безпосередньо впливають на формування фотосинтетичної продуктивності посівів сої, можна віднести строки сівби та за- 
стосування мікродобрив різними способами.

3. Проведення позакореневих підживлень рослин сої мікродобривами «Рексолін» і «Брасітрел» на фоні обробки насіння «Рексоліном» за раннього строку сівби сприяло збільшенню площі листкової поверхні. Кращий результат відмічено за обробки насіння «Рексоліном» і позакореневого підживлення «Брасітрелом» - 33,0

\section{БІБЛІОГРАФІЯ}

1. Бабич А. О. Сучасне виробництво та і використання сої. - К. : Урожай, 1993. - 432 с.

2. Ничипорович А. А. Фотосинтез и теория получения высоких урожаев. - М. : Изд-во АН CCCP, 1956. - $330 \mathrm{c}$.

3. Ничипорович A. A. Фотосинтез и вопросы интенсификации сельского хозяйства. - М. : Наука, 1965. - 47 с.

4. Ничипорович А. А. Фотосинтетическая деятельность растений в посевах / А. А. Ничипорович, Л. Е. Строганова, М. П. Власова - М. : AH CCCP, 1969. - $137 \mathrm{c}$.

5. Паменко О. I. Формування асиміляційної листкової поверхні сої залежно від способів основного обробітку грунту та рівня мінерального живлення / Бюлетень інституту зернового госпо- тисячі метрів квадратних із гектара.

4. Максимальні показники чистої продуктивності фотосинтезу було зафіксовано в міжфазний період «утворення бобів - наливання насін-

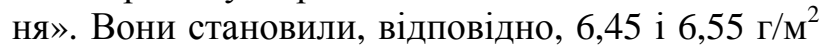
за добу на ділянках раннього строку сівби за комплексного застосування мікродобрив для обробки насіння і по вегетуючих рослинах.

дарства УААН. - Дніпропетровськ, 2009. - №37. (http://www.institut-erna.com/library/pdf37/10.pdf).

6. Рослинництво. Практикум / За ред. О. І. Інченка. - Вінниця : Нова книга, 2008. - 536 с.

7. Стоцька С. В. Динаміка наростання листкової поверхні та концентрація хлорофілу в конюшині лучній залежно від впливу агротехнічних прийомів вирощування в умовах Полісся / Корми і кормовиробництво. - 2008. - Вип. 62. C. $112-118$.

8. Холодченко Р. М. Фотосинтетична діяльність посівів вівса голозерного залежно від умов мінерального живлення та норм висіву / Корми i кормовиробництво. - 2013. - Вип. 77. - С. 280285. 